\title{
Perestroika and Persons with a Physical Disability ${ }^{1}$
}

Sean Atkins

ABSTRACT: Perestroika brought important changes to the place in Soviet society of persons with a physical disability. The administrative and bureaucratic changes of the Soviet government, including those affecting social security benefits, and the increased involvement of persons with a disability in governmental and nongovernmental organizations were vital to the changes. The establishment of the AllRussia Society for the Disabled in 1988 reflected the growth of private and public charity. The media began encouraging public response, leading to the growth of local and community relief organizations. The media also provided a forum in which persons with a physical disability could be heard. The period between 1988 and 1991, however, revealed how enormous the task of social rehabilitation would be. Although the Soviet government acknowledged the rights and needs of persons with a physical disability it did not and could not provide enough money to deal effectively with these needs.

Perestroika ushered in a new era in the relationship between state and society in the Soviet Union. It was a policy of social and economic restructuring engineered from above, but fully expecting support and initiative from below. By the end of 1991, the ramifications of perestroika had been largely responsible for bringing down the political establishment and marking the end of over seventy years of Communist rule. Economic and social restructuring affected the daily lives of almost everyone but none more than those, like persons with a physical disability, who had been especially disadvantaged.

More than 10 percent of the world's population has a disability. In most countries, at least 10 percent of the people have a physical, mental, or sensory impairment, and the presence of disabilities adversely affects at least 25 percent of the entire population. ${ }^{2}$ Even these statistics do not fully reveal the immensity of the problem since many persons frequently live in deplorable conditions, owing to 
the presence of physical and social barriers that prevent their integration and full participation in the community. ${ }^{3}$

Perestroika (1988-1991) ${ }^{4}$ had important ramifications for persons with a physical disability. The success of perestroika depended largely on the involvement of individuals and organizations outside government. However, the state-centred political culture of Soviet life meant that the impetus for change would come from the political elite. Consequently, the administrative and bureaucratic changes of the Soviet government, including those affecting social security benefits, were important to persons with a physical disability. The involvement of persons with a physical disability in governmental and nongovernmental social movements was also vital if their everyday life was to change. Concerning nongovernmental social movements, the reintroduction of private and public charity engendered statewide philanthropic associations and influenced the establishment of the All-Russia Society for the Disabled (Vserossiskaya Organizatsiya Invalidov, [vol]). The media helped shape public response, especially the establishment of local and community relief organizations. The media also provided a means by which persons with a physical disability could make their voices heard. Indeed, perestroika stimulated the growth of personal and public consciousness; it encouraged social initiative and individual involvement. Above all, however, the period between 1988 and 1991 revealed how enormous the of the task of social rehabilitation would be. The Soviet government acknowledged the rights and needs of persons with a physical disability but did not and could not provide enough money to deal effectively with the problem.

\section{Scholarly Approaches and New Sources}

Soviet scholarship before perestroika largely ignored the daily life experiences of persons with a disability. There are few case studies and no personal accounts. There are no works on disability and social interaction and virtually no discussion in local newspapers or local magazines. Indeed, 
apart from a purely medical-scientific analysis, it is difficult to form a picture of life for persons with a disability before perestroika. $^{\text {s }}$

Western literature on persons with a disability in the Soviet Union before perestroika is limited, largely because of the scarcity of Soviet sources. ${ }^{6}$ The Disabled in the Soviet Union ${ }^{7}$ is the only volume in English dedicated entirely to the position and treatment of persons with a disability in the Soviet Union. The book is a series of essays by several scholars, dealing with an array of historical and contemporary topics that mirror the complexity and unique characteristics of the social makeup of persons with a disability. The Disabled in the Soviet Union strikes a balance between those administrative, medical, and political institutions that governed the conditions of life for persons with a disability and the popular attitudes that immeasurably shaped them. This book, broad but diverse, opens avenues of informed research previously unexplored. ${ }^{8}$

Since the mid-1980s, owing to the emergence of several new sources, it has been possible to learn much more about the place that persons with a physical disability have had within Soviet society. These sources supplement the standard medical-scientific approach with a more revealing socialscientific one. It was only with perestroika that new research and lively discussion occurred outside the dry conformity and limited circulation of the medical journals.

Perestroika enabled the popular press and local newspapers to report openly on the living and working conditions of persons with a physical disability. The official press became a source for information on governmental response to the social, economic, and cultural issues affecting these people. After 1987 their conditions became the concern not only of the official press but also of the mass and popular media. Party and government newspapers like Pravda (Truth) and Izvestiya (News), remained virtually silent on daily life in the Soviet Union but glasnost (openness) in popular magazines like Ogonek (The Flame) and the "revolutionary" reorientation of newspapers like Moskouski Novosti (Moscow News) encouraged people to write openly about 
problems that affected them personally. Furthermore, the major sports newspapers and journals in the former Soviet Union have reported on persons with a physical disability in sport both domestically and internationally since $1986 .{ }^{9}$ Finally, the contributions by nongovernmencal and civic organizations to the formation of national and international policy making, not to mention public awareness, have been significant.

\section{Government Reforms}

One-third of the 552,000 men and women first certified as disabled in the Soviet Union in 1988 were in what should have been the prime of life. ${ }^{10}$ There are indications that the government was serious about reforming social security administration as it related to these people. The introduction of local Social Help Sections in January 1987 had been a significant step." In December 1986, trade unions, the Komsomol, Societies for the Blind, Deaf and Dumb, and the Red Cross supported the establishment of the AllUnion Organization for Veterans of War and Labour. Although the Union had many tasks, part of its program included integrating persons with a physical disability and pensioners into acceprable working environments, improving housing conditions, increasing social and medical services, and defending the rights and voices of persons with a physical disability. ${ }^{12}$

An article in Izvestiya in April $1988^{13}$ explained how the changes in social security would benefit those in need. Changes to the social security system would deal with "the broader task of solving the problem of material provision of old people, invalids, and others who cannot work, in a comprehensive manner." Social service efforts were made to increase help at home as much as possible; set up territorial social-service centres in which pensioners and persons with a physical disability could stay permanently or temporarily; and construct more homes;

homes containing 17000 places could be built from the funds unused in the last three five-year plan periods. The 
situation is no better with the construction of special houses with all domestic services and work-rooms for single, elderly citizens-only eighteen have been built.

Solving this problem should be a priority for social security organs and local Soviets. We also hope that the press will help ... . At the present time there are one and a half thousand enterprises, shops and work sectors designed for employing invalids. That's extremely few ... . As a result of the transition to self-financing and profit making there is a reduction in work-places everywhere ... . Large enterprises arc hardly likely to create special workshops for invalids.

In our view the answer lies in creating small enterprises and employment centres oriented to serving them ... . Local Soviets should look into the matter... We set great store by the republican Soviets for invalids now being established. They could help not only in finding work and professional instruction, but also in organizing leisure activities.

Take the work of the social security organs in Lithuania. The staff there do not wait for people to come to them with complaints or explanations. They regularly organize outside meetings, and invite the heads of organizations to come along and decide questions on the spot. With the help of the press, radio and television they give information about their plans and new benefits, and they bring up serious problems for discussion. However, this is nor done everywhere. There are many complaints of indifference, heartlessness, and formal attitudes to labour veterans and invalids. ${ }^{14}$

This article signified a new approach in the relationship between state and society that went beyond the mere increase in material assistance. The government invited the public to become involved in the reorganization of social-security administration. A large part of this seemed to imply an administrative shift from the centre to the local levels. It encouraged independent societies for persons with a physical disability and more attention to labour rehabilitation. A more "personal" approach to rehabilitation between patient and physician was also stressed. Finally, it invited the media to take part in the information process.

Perestroika looked towards a complete overhaul of the system of pensions. The tasks that lay ahead, however, were 
daunting. Between 1980 and 1987 the total number of pensioners of all kinds increased from 50.2 to 57.7 million. ${ }^{\text {s }}$ By early 1987 over 20 percent of the population were pensioners. ${ }^{16}$ The following year, there were just under 60 million pensioners. For every 100 people of working age in 1989 there were 37 pensioners, compared to 32 out of 100 in $1980 .{ }^{17}$ Pension payments in 1989 totalled 55 billion rubles, a 70 percent increase since $1980 .^{18}$ The prices of goods and services grew by 4.5 percent a year, yet by the end of 1988 there had been no major reform of the socialsecurity system and the basic minimum rates for persons with a disability remained unchanged at between 30 and 50 rubles a month depending on the recipient's age and category of disability. The average worker's salary was about 200 rubles a month. More pensioners were dropping below the official subsistence level of 75 rubles a month in $1986 .{ }^{19}$

The Soviet government recognized the need for change and moved quickly. On 4 August 1989, Izvestiya published the "Law of the Union of Soviet Socialist Republics on Urgent Measures to Improve Pensions and Social Services for the Population. ${ }^{20}$ The law concained eleven articles covering pensions and social services reforms for war and labour veterans, persons with a disability, and families of deceased military personnel. All measures were to take effect between 1 October 1989 and 1 January 1990.

Pensions for persons with Group I disabilities ${ }^{21}$ were to be raised to 85 rubles per month, and to 70 rubles per month for those with Group II disabilities. Monthly state subsidies to people who had received their disability in childhood was to grow to 70 rubles for persons with Group I disabilities, 50 rubles for persons with Group II disabilities, and 70 rubles for children under the age of sixteen with a disability.

In an attempt to extend the pension system to all of the country's non able-bodied citizens, provision was made for the establishment of two types of pensions: labour-based pensions, which were previously in effect, and newly introduced social pensions. Although there were several changes to labour-based pensions, especially in the 
mechanism for calculating pensions, ${ }^{22}$ the introduction of social pensions signified a fundamental change in state policy.

Proceeding from the principles of universal pension coverage, humaneness, and social justice, the government and the All-Union Central Council of Trade Unions proposed that social pensions be established for those who, for one reason or another, did not acquire the right to a labour-based pension. Persons who had a disability since childhood (about 1.5 million people) would thus become eligible. The size of social pensions would depend upon various factors, including the extent of disability. Group I persons would receive social pensions set at 100 percent of the minimum old-age pension (70 rubles), Group II persons at 50 percent, and Group III at 30 percent.

According to preliminary estimates, the pension reform would cost 29 billion rubles a year. This was in addition to the 6.5 billion rubles required to implement the already adopted Law on Urgent Measures to Improve Pensions. The increases in expenditures on improved standards of living jumped by 14 billion rubles from the entire Tenth Five-Year Plan (1976-1980), and by 13 billion rubles from the current Five-Year Plan.

The proposed pension reform also brought a reorganization of sources for paying pensions. It proposed to replace scattered funding with a single pension fund for the country. This fund would be formed from money paid by enterprises, organizations, collective farms, and other cooperatives for social insurance purposes in accordance with established tates, from insurance contributions paid by citizens involved in individual enterprise, and from state budget monies. Increases in the size of pensions and related expenditures also meant an increase in the rates for social insurance contributions from enterprises and organizations. Estimates showed that, to introduce the new pensions, contributions, on average, would have to increase from 12 percent to 30 percent of the wage fund. ${ }^{23}$

Like other plans before it, the government plan fell far short of actually affecting the daily living conditions for 
persons with a physical disability. On the one hand, the introduction of social pensions alongside labour pensions signified government recognition of the right of all persons to the enjoyment of life on equal terms. The utilitarian, state-centred labour pension was clearly incompatible with the universal people-centred concepts of perestroika. On the orher hand, it remained to be seen whether an increase in contributions from the wage fund was possible when salaries were not keeping up with increases in the cost of living. Moreover, the increases in pension payments in no way mirrored the enormous increases in the cost of living. The creation of a single, universal pension fund suggested that the administration of this fund would still be centralized. It was unclear how any financial support would be distributed to those who required it. Finally, a comparison of state investment in social-security with investment in other areas reveals that priorities lay elsewhere. The cold-war legacy lingered. In the first quarter of 1991 , a Soviet economist estimated that defence expenditures were running 50 percent higher than the total revenues of the Soviet government. ${ }^{24}$ In addition, in 1990 Foreign Minister Eduard Shevardnadze, at a session of the 28th Party Congress in Moscow, claimed that the military, monopolizing one-fourth of the national budget, had wasted 700 billion rubles in Cold War spending excesses. ${ }^{25}$ These numbers put the allotment of 35.5 billion rubles for pension payments and the 13 billion rubles increase for the current Five-Year Plan into perspective. In this respect, government measures were not so different from those of the past. It seemed as though the increases were merely stop-gap measures taken for cosmetic reasons.

\section{Increased Involvement of Persons with a Disability}

The 1989 elections for the Congress of People's Deputies brought several prominent deputies with a physical disability to the highest body of state authority. Nikolai Engver was born in the Potma labour camp southeast of Moscow in the Mordvin ASSR, where his mother was placed because her husband was judged an enemy of the people in 1937. 
Engver had been born with polio, and could walk only with the help of two canes. He had been a member of the Communist Party since 1975, but was at one time expelled from the Komsomol for criticizing Khrushchev's 1956 "cult of personality" speech. Upon his election, Engver was appointed Chairman of the Subcommittee for Social and Economic Problems of Youth within the Committee of the Supreme Soviet of the USSR for Youth Affairs. ${ }^{26}$

Ilya Zaslavsky was nominated as a candidate for deputy of the Supreme Soviet by the Oktyabrsky (October) District Organization of the All-Russia Society of Disabled (Moscow). ${ }^{27}$ Later in the year, Zaslavsky was elected to the Supreme Soviet and was made Deputy Chairman of the Committee of the Supreme Soviet for the Affairs of Veterans and the Disabled. ${ }^{28}$

Zaslavsky pushed hard for better living and working conditions for persons with a physical disability. His election platform had included:

regular cost of living pension increases, ... tax excmptions for enterprises run by the Society of the Disabled ... boarding schools for disabled students at higher and technical schools ... [and] a network of enterprises and cooperatives under the All-Russia Society of Invalids. ${ }^{29}$

In an interview with Izvestiya in August $1989,3^{30}$ the newly elected Zaslavsky remarked that, for many years, the problems of persons with a physical disability officially did not exist. For example, the president of the German firm Meyer, which wanted to produce wheelchairs in the Soviet Union, was told that this was unnecessary because there were no needy persons with a disability in the Soviet Union. ${ }^{31}$ Zaslavsky also commented on the Committee of the Supreme Sovier for the Affairs of Veterans and Disabled, and its ability to work with the larger community. Complaints to the Committee allowed it to "analyze typical situations and make working contacts with agencies with executive powers." 32 
Zaslavsky recognized the connection between better living conditions for persons with a physical disability and the general economic health of the country:

The disabled live poorly because, for now, many people live poorly because of the low economic level of the country...[O]ur economy needs much more than elsewhere in the world to achieve analogous results ... But is it really easier for the rural disabled because the country produces more metal than others if the disabled person himself doesn't have enough iron for his roo?

In order to help the disabled, we must first of all improve the country's economic situation. But new reforms in the economy are impossible without political reforms, without democratic elections on all levels on a competitive basis. Precisely for this reason, I took part in the working out of various proposals directed toward the general improvement of life in the country. In particular, I took part in the work of the Moscow Deputy's Club and of the Inter Regional Deputies Group. ${ }^{33}$

Unless the country's overall economic situation was improved, Zaslavsky remarked, nothing would get better for anyone and "all attempts will be like pulling on a ragged blanket which threatens to tear apart. ${ }^{34}$

The Congress also allowed many deputies to voice their concerns over the interrelated issues of economic and environmental mismanagement and its effects on personal well-being and health. On 2 June 1989, the first secretary of the Cherkassy City Komsomol Committee in Ukraine spoke for persons with a physical disability. As an army major crippled in Afghanistan, the deputy spoke about the right to receive proper prosthetics equipment:

It is an insult [to the state] to have rationing coupons in the 72nd year of Soviet power, an insult in the collapse of the economy, the devastated villages ... the fishless rivers and the cities with chemical smog ... .

Comrades, I will not beat around the bush. My prostheses were manufactured on equipment at one of the two prostheses plants given to us after the war by Churchill's wife. Yes, 
respected scientists, it is possible to mow with a 12 th century model scythe, and even do a good job with it, but I would not even wish it upon my enemies to have to move around with such deformity at the end of the 20th century. ${ }^{3 s}$

Public involvement at the community level was also crucial in the labour and social rehabilitation of persons with a physical disability. The International Meeting on Human Resources in the Field of Disability, in Tallinn, Estonia, from 14 to 22 August 1989 showed that the role of government and nongovernmental organizations was vital for the rehabilitation and self-determination of persons with a disability in the community. The accive participation of these people in nongovernmental organizations was considered crucial. Many speakers considered communitybased rehabilitation best suited for all areas of the country. The involvement of the family and the community was essential to such rehabilitation. ${ }^{36}$

The Tallinn conference also contained guidelines on the promotion of employment:

Disabled persons have the right to be trained for and to work on equal terms in the regular labor force. Community-based rehabilitation programmes should be encouraged to provide better job opportunities ... .

Employment opportunities can be promoted primarily by measures relating to employment and salary standards that apply to all workers and secondarily by measures offering special support and incentives. In addition to formal employment, opportunities should be broadened to include self-employment, cooperatives and other group incomegenerating schemes. Where special national employment drives have been launched for youth and unemployed persons, disabled persons should be included. Disabled persons should be actively recruited, and when a disabled candidate and a non-disabled candidate are equally qualified, the disabled candidate should be chosen.

Provision was made for the employment of women with a disability:

Employers' and workers' organizations should adopt, in cooperation with organizations of disabled persons, policies 
that promote the training and employment of disabled and non-disabled persons on an equal basis, including disabled women.

Policies for affirmative action should be formulated and implemented to increase the employment of disabled women. Governments and non-governmental organizations should support the creation of income-generating projects involving disabled women. ${ }^{37}$

It remains to be seen whether women with a physical disability can make significant advances in employment since previous studies on women with a physical disability and employment in the United States have illustrated that much is still needed. ${ }^{38}$

\section{Philanthropic Associations}

All-Union charitable funds like the V.I. Lenin Children's Fund ${ }^{39}$ and the Soviet Health and Charity Fund enjoyed both public support and government cooperation. ${ }^{40}$ Because both funds were considered public organizations, they were guaranteed representation in the Congress of People's Deputies. In the 1988 elections of People's Depuries, the two funds held five seats each. ${ }^{41}$ Thirty prominent members of the Children's Fund were elected to, or selected for, the Congress. ${ }^{42}$

The Soviet Health and Charity Fund consisted of organizations for persons with a disability and many orher state and public organizations. It held its All-Union Constituent Conference in Moscow on 16 September 1988. S.N. Fyodorov, chair of the fund's organizing committee, outlined the scope of activity and general casks of the fund. ${ }^{43} \mathrm{He}$ noted the growing number of local groups of volunteers and associations in Moscow, Leningrad, Gorky, and Tbilisi, among other cities. He also commented on the inability of rest homes to meet the increasing demands of elderly persons with a disability. Supplies of food, medical supplies, and space were critically low at some rest homes. Furthermore, not only was there a shortage of wheelchairs, but the ones available were cumbersome, heavy, and hard to steer. Prostheses were even more inadequate. ${ }^{44}$ 
Fyodorov pledged that monies from the fund would help equip and furnish rest homes, improve the quality and quantity of prostheses, and produce "special equipment" to make life easier for persons with a physical disability. He also explained that the fund was considering rendering medical, social, and consumer assistance to a home for the elderly and persons with a physical disability, and to war and labour veterans with a physical disability who lived alone. The fund also pledged to promote public health, social security, physical education, and sport. Finally, Fyodorov explained that all financing would come from scate, public, and cooperative organizations; proceeds from events organized by the fund (various lotteries, auctions, concerts, book sales, film rentals); contributions from individual citizens; and foreign currencies.

The V.I. Lenin Sovier Children's Fund expanded quickly after its inaugural conference in October 1987. By December 1988 , local bodies had been established in nearly all oblasts, krais, and republics. It had a full-time staff of $500-600$ persons and nearly 10,000 volunteers. The full-time staff was not paid from public contributions but from other sources like returns from the fund's journal Semia, and several commercial cooperatives, including a clinic, a familyservices unit, and a milk-processing centre. ${ }^{45}$ In 1988, its first full year of operation, the Children's Fund received 43 million rubles in donations. ${ }^{46}$

The Children's Fund was instrumental in providing services to children with a physical disability, but the task was formidable. One of the fund's first projects, in 1987 , mobilized emergency medical teams from around the Soviet Union to reduce infant morcality (estimated in the late 1980 s at at least 33 per thousand) in various cities of Central Asia. ${ }^{47}$ Although the fund did save lives, its impact was local and transitory, owing to terrible conditions and outdated equipment. ${ }^{48}$ In many areas, residents had no knowledge of programs for which they were eligible. In Irkutsk, for example, the Children's Fund found that there were 3,158 children with a severe disability but that many of their parents were unaware of the allowances and other forms of state assistance available to them. ${ }^{49}$ 
The Children's Fund was also interested in the living conditions $^{50}$ and educational options open to children with a physical disability. Although the fund had no intention of intervening directly in the school curriculum, ${ }^{51}$ it urged that facilities for children with a physical disability be incorporated in new schools and ramps be placed in old schools. The fund was also involved in the establishment of a centre for the creative rehabilitation of children with a physical disability in Moscow. It was intended to identify the gifted among them, to develop their creative powers, and to ease their integration into society. The fund proposed to grant scholarships to these children, to augment those that it granted to gifted children in the general population (14 in 1989 and 145 in 1990), so that they could study at such premier institutions as the Moscow Conservatory of Music.52

The fund also pushed for changes in the care and institutionalization of children with a physical disability. In an interview in Pravda in October 1988, ${ }^{53}$ the chair of the fund, Albert Likhanov, suggested that keeping a child with a physical disability in a state institution would cost the public treasury several times more than a significant increase in disability pensions would. Likhanov brought forward three proposals for nationwide discussion. First, he suggested that on every Children's Day (1 June), all people and enterprises, collective farms, and institutions conduct another all-Union volunteer workday or set aside another day of unpaid work, transferring all the money earned to the Children's Fund. Monies received would assist families who were rearing children with a physical disability. He also suggested that all enterprises be required to devote 3 percent of their workplaces to persons with a disability, after organizing special classes for their vocational training. If the 3 percent were not filled, these enterprises should allocate to social security or the Children's Fund sums equalling the average wages of the employees occupying these jobs. Finally, Likhanov suggested that the Supreme Soviet, the Party Central Committee and the Council of Ministers direct part of the money from the reduction of 
military programs, emphasizing the fact that they were doing so, to children with a disability and those receiving their disability in childhood.

The All-Russian Society for the Disabled

The Initiative Group to Defend the Rights of the Disabled in the USSR, an independent society for persons with a physical disability, ${ }^{54}$ realized its most important demand of the 1970s with the establishment of the All-Russian Society for the Disabled in 1988. The government's position on the right to organize had changed considerably since the late 1970s. In an article in Izvestiya in February 1988, N.T. Trubilin, vice-chairman of the Russian Republic's Council of Ministers remarked that the decision to establish a society for persons with a physical disability was successful

primarily because of disabled people's desire to play a more active role in public life, to have broader opportunities for socializing, and to hold the kind of jobs they are capable of handling and at which they can be most productive. The latter is especially important, as it gives them a sense of independence and the knowledge that they are being useful to society."

Trubilin also remarked that although there were over four million persons with a physical disability in the Russian Republic, and nearly 350,000 people were declared disabled each year, just over one million were placed in jobs at the time. Further, more than half of these were healthy enough to work. Trubilin also referred to the societies of the blind and deaf that had been operating for several decades, successfully overseeing the social and labour rehabilitation of those with hearing and visual disabilities. These societies had twenty production associations and 139 productiontraining enterprises, and, among other facilities, operated clubs, sanatoria, vacation homes, hotels, and a mime-studio thearre. ${ }^{56}$

A constituent conference held on 16-17 August 1988 created the Russian Republic Society for the Disabled. This 
conference confirmed a Charter and elected a Central Board. Such issues as job placement, occupational training, medical and social rehabilitation, consumer service and everyday assistance, medical supplies, high-quality prostheses, carts, wheelchairs, and better specialized motor transport were all raised. One of the most important issues, however, was the question of the social and occupational rehabilitation of persons with a physical disability. The key to this issue was job creation and special producer cooperatives, something that had been eliminated in 1956. ${ }^{57}$

The founding conference was emotional, and not without controversy. An article in the popular magazine Ogonek8 revealed just how explosive the conference was. A range of important issues was discussed, including the ambiguities of the Charter with respect to financing, the neglect of children with a disability, and the existing division of people into three groups of disability.

The most important controversy at the conference concerned the reluctance of the central government to turn financial and administrative issues over to regional and local governments. Some argued that a centralized social-security administration could not work in a country that simply could not afford to take care of those who needed support. Transferring more fiscal and administrative power to those requiring support would make the lines of cooperation more direct and help to encourage greater initiative. In a 1989 article published in Sotsial'noe obespechenie [Social Security] in 1989. ${ }^{59}$ Sergei Germanovich D'iachkov, chairman of vol from Autoplant Raion in Tol'iatti, Volga region, reported that in a survey taken of the 5,000 persons with a physical disability in Autoplant Raion in Tol'iatti, only 11 percent had joined vol. Forty percent did not join because they did not know what the organization was about, 22 percent because they did not want to cooperate, and 27 percent because vol had done nothing for them. D'iachkov was also harassed by local authorities over funds contributed to vol ${ }^{60}$ In Perm Oblast, the local security directors, chiefs of shops, deputies, and the Sports and Engineering Commission were giving vol a hard time. At 
that time, in Perm Oblast, vor had neither a building, nor a base for production, nor transport.

At the founding conference the minister of social security of the Russian Republic, V. Kaznacheev, promised that "a truly humanistic approach to the disabled is not a slogan, and not a campaign, but one of the links of state policy in the social sphere." Kaznacheev also admitted that the situation was worsening. He pointed out that in 1987 more than 45,000 persons with restricted work abilities were employed, which was almost 100,000 more than before April 1985. However, in 1987, only 30 percent of the total number of persons with a disability were employed, which was actually 4 percent less than in 1985. Among those employed, Group III persons were doing the best (79 percent); only 10 percent of Group II persons and 9 percent of Group I were employed. A study revealed that about $\mathbf{4 0}$ percent of persons with a disability were unhappy with the character and content of their work, and 39 percent were not satisfied with their working conditions. ${ }^{61}$ Clearly the issue of employment and occupation was only getting worse as the Soviet Union moved away from a centrally planned system. The government recognized it but could offer very little.

D'iachkov also criticized the Minister of Social Security, remarking that the government's statements as "we are posing the question of the creation of complexes in which people live and work" did not lead to programs that addressed the problems that the question raised. He challenged the administration of vol, remarking that although the society had been established, no organization defended persons with a physical disability. For example, no more than 8 to 9 percent of the 100,000 persons with a disability in Kuibyshev Oblast in the Urals had joined the organization. vol was created from above, he remarked, and remained tied to the structure of the Ministry of Social Security. "Fatally incompetent" administrators had the right to distribute funds, use privileges, and take advantage of possibilities. Those specialists among persons with a physical disability were kept from the management of affairs. ${ }^{62}$ 
The initial day-to-day experiences of the society proved to be daunting. For example, those members of the society in the Kuibyshev raion (district) ${ }^{63}$ of Moscow found it difficult to determine how many persons with a physical disability lived in their area. Although the Communist Party readily gave the society facilities with their own telephone line, information on addresses given to members at the raion social security department and at several adult and children's polyclinics were of limited use. Moreover, Moscow's information line was costly: two requests for telephone numbers were free, but each additional request cost fifteen kopeks. ${ }^{64}$ Despite controversies within the community, however, the society established relations with interest groups abroad. For example, in September and October 1988, the Moscow Sociery of Disabled hosted a delegation which included American Viernam veterans, "prosthetists, an orthopaedic surgeon, readjustment psychologists, computer designers and transportation (wheelchair) specialists." Earthstewards Network (Washington State) and the Soviet Foundation for Social Inventions organized the trip. ${ }^{\text {SS }}$

\section{The Public Media}

As part of perestroika, the Soviet government encouraged public initiative. This change in policy directly affected persons with a physical disability. At first, the media helped publicize the work of local charitable organizations. ${ }^{66}$ Questionnaires and essays on charity and other forms of material support revealed widespread public interest. ${ }^{67}$ The media also revealed the everyday living and working conditions of persons with a physical disability. In January 1988 the Soviet television show "First Program" broadcast a segment called "Nashi Dolgi" (Our Debrs), which was one of the rare instances in which Soviet television showed persons on crutches or in wheelchairs. ${ }^{68}$

Moscow News began running many articles on aspects of life for persons with a physical disability. Some of these articles discussed unsatisfactory living conditions in special 
clinics, rent-free and private ownership housing for persons receiving a disability in World War II, and the conversion of reception houses, government dachas, and cottages in Armenia to holiday homes for orphaned children and war and labour veterans. ${ }^{69}$ Human interest stories and vignettes featured persons with a physical disability. ${ }^{70}$ The paper even reported on public protests by persons with a physical disability. For example, it ran a story on a hunger strike by Soviet Afghanistan veterans who were demanding action on a much promised training and rehabilitation centre. ${ }^{11}$ In September 1989, on the occasion of the opening of the Supreme Soviet, it reported on a demonstration in Red Square by persons with a physical disability who were protesting working conditions in a local factory. ${ }^{72}$ It also published letters from persons with a physical disability explaining how perestroika and the reintroduction of worker cooperatives brought higher earnings, better medical assistance, and social benefits. ${ }^{73}$

Because of perestroika, the media for the first time ran stories on the lack of accessibility to buildings and public transportation for persons with a physical disability. In February 1989, Ogonek reported on the lack of wheelchair accessibility in Moscow and the City Soviet's Executive Committee's refusal to act on the issue. ${ }^{74}$ After receiving a letter asking all the charitable Christian and human rights institutions to help persons with a physical disability living in homes purchase buses, Moscow News called on its readers to help. The paper described a Leningrad boarding school that resorted to using a hearse to transport clients to cultural events and exhibits. ${ }^{\text {? }}$

\section{Conclusion}

The Soviet government reformed social-security administration and increased pensions and benefits as a part of its policy of perestroika. Though significant, the reforms proved to be inadequate because the benefits were too restricted, inflation eroded purchasing power, and the 
reforms were too "top-down." Furthermore, not only was the pension and social-security administration virtually bankrupt, people who sought benefits had to fight their way through a bureaucratic maze.

Significant and worthwhile change only occurred at the community and nongovernmental level. In 1988, persons with a physical disability were elected to the Congress of People's Deputies; for the first time they were actively involved in the affairs of the state. In another ourgrowth of perestroika, the interests of persons with a physical disability benefitted from local and statewide charitable funds. Furthermore, these people were represented in the administration of the funds, putting them in a more directly responsible position. Significantly foreign and international charitable organizations also appeared. Among them was the Salvation Army which was reestablished in 1991 after a sixcy-eight-year hiatus. ${ }^{76}$

The establishment of an All-Russia Society for the Disabled was the culmination of ten years of work combatting social and legal obstacles. The establishment of a such a society had long been prevented even though the visually and hearing impaired had their own organizations. The society envisioned its main role to be labour and social rehabilitation. For example, the society strongly supported the reintroduction of worker cooperatives. The society also enabled persons with a physical disability living in the Russian Republic to present their views in an organization which they could call their own. The early organizational and financial difficulties of the society should not be overlooked, but the society allowed its members to take an active part in public life in a period of rapid change in state and society. Despite D'iachkov's well-founded criticisms concerning finance and administration, his ability to speak freely without fear of reprisals represented a major step on the road towards a freer society.

Finally, the media provided a vital link between the ablebodied and persons with a disability in the Soviet Union. The public had long been ambivalent towards persons with a physical disability; a combination of rigid ideology and 
unwavering silence in the press convinced them that the state was taking care of these people. As a result of perestroika, the media informed the public about the real situation of persons with a physical disability.

Since the mid-1980s, the relationship between state and society has been continuously questioned and reexamined. Social initiative and grass-roots organizations have emerged to challenge traditional Russian political culture characterized by centralization, bureaucracy, and repression. Change has been slow in coming, but persons with a physical disability have been participating in restructuring and are determined to see change come about regardless of the pace. As Ilya Zaslavsky commented in the summer of 1990, "It's a terrible thing to have a democracy that talks but doesn't work. After so many years of silence, people expect great change. ${ }^{n 7}$

\section{NOTES}

IPlacing the individual above his or her abilities, this paper follows guidelines set forth by the Government of Canada, Fitness and Amateur Sport in "Words with Dignity: Active Alliance for Canadians with a Disability." These guidelines will also be observed in references to previous works on persons with a disability outside the Soviet Union, even if a different term is provided; however, for the sake of historical accuracy, Soviet terminology and definitions are maintained in all references and sources.

${ }^{2}$ Leandro Despouy, Human Rights and Disabled Persons (New York: United Nations, 1993), 1.

slbid.

4For more on Perestroika, see Mikhail Gorbachev, Perestroika-New Thinking for Our Country and the World (New York: Harper and Row, 1987).

'One of the rare exceptions was a study published in Sotsiologicheskie issledovaniia [Suciological Research] 4(1988): 79-83, which attempted to determine how an independent society for persons with a physical disability could increase employment opportunities and stimulate integration into public life.

'See Bernice Q. Madison, Social Welfare in the Soviet Union (Stanford, California: Stanford University Press, 1968), 184-6; 202-6; and Ludmilla Alexeyeva, Soviet Dissent (Connecticut: Wesleyan University Press, 1985). 
TWilliam O. McCagg and Lewis Siegelbaum, eds., The Disabled in the Soviet Union (Pittsburgh: University of Pittsburgh Press, 1989).

${ }^{8}$ One area of academic research that benefitted greatly during perestroika was the study of the education system in general and special needs education in particular. See Barbara A. Anderson, Brian D. Silver and Victoria A. Velkoff, "Education of the Handicapped in the USSR: Exploration of the Statistical Picture," Soviet Studies 39 (3) Ouly 1987): 468-88; Andrew Sutton, "Special Education for Handicapped Pupils," chapter 4, in Jim Riordan, ed., Soviet Education: The Gified and the Handicapped (London: Billing \& Sons, 1988), 70-94; V. Lubovskii, "Some Urgent Problems of Soviet Work with Handicapped Children," Soviet Education 31 (5) (May 1989): 50-67; Anthony Jones, "A Conception of Special Education and Upbringing of Children with Impaired Mental and Physical Development," Soviet Education 32 (10) (October 1990): 50-67; and Landon Pearson. Children of Glasnost: Growing $U_{p}$ Soviet (Toronto: Lester \& Orpen Dennys, 1990), 173-95.

'On sport and disability during perestroika, see Sean Atkins, "Whither the "New Soviet Man'?: Persons with a Physical Disability in the Soviet Union, 1975-1993" (MA Thesis, University of Alberta, 1993), ch. 4. Also sec Moscow News 10 (1987), 15; 25 (1987), 15; 2 (1990), 10; Ogonek 12 (March 1987): 14-15; Sport v SSSR 6 (1987): 26-8; Sport in the USSR 5 (1988): 48-52; Sobesednik [Childhood], 37 (September 1987): 12; Soviet Life (June 1987): 12-14; The Station Relay 2 (4) (March 1987): 17; Disability Today 2 (1) (Fall 1992): 49; 2 (3) (Spring 1993): 5; and The Journal of Leisurability, 15 (2) (Spring 1988): 30-31. Also see Jim Riordan, "Playing to New Rules: Soviet Sport and Perestroika," Soviet Studies 42 (January 1990): 133-145; and Pearson, Children of Glasnost, 180-1.

${ }^{10}$ Murray Feshbach and Alfred Friendly Jr., Ecocide in the USSR(New York: Basic Books, Harper Collins, 1992), 190. For more on disability classification, see note 21 .

"Sec Pravda, 5 October 1986, 3; and Moscow News 11 (1987), 14.

"Mervyn Matthews, "Perestroika and the Rebirth of Charity," in Anthony Jones, Walter D. Connor, and David E. Powell, eds., Soviet Social Problems (Boulder, Colorado: Westview Press, 1991), 158.

13/zuestiya, 21 April 1988, cited in Matthews, "Perestroika and the Rebirth of Charity," 158-9.

${ }^{14}$ Ibid.

"Matthews, "Perestroika and the Rebirth of Charity," 160.

${ }^{16}$ Moscow News, 4 (1988), 12.

${ }^{17}$ Pravda, 3 November 1989, 1-3, cited in The Current Digest of the Soviet Press 41 (45): 15.

18Ibid.

${ }^{19}$ Moscow News, 2 (1989), 10. 
${ }^{20}$ Izvestiya, 4 August 1989, 1; cited in The Current Digest of the Soviet Press 41 (38): 20.

${ }^{21}$ The idea of total or partial incapacity for work because of illness or accident formed the basis of all legislation on persons with a disability in the Soviet Union. All persons with a disability were classified on their ability to work: Group I included those who had lost all capacity for work and required constant care; Group II lost the capacity to work efficiently in their former or any other occupation but could possibly work under special conditions, but did not need constant nursing care; Group 111 included those whose loss-of-work ability may be as high as two-thirds and were unable to work in their former occupations under pre-injury conditions. Nevertheless, they could engage in casual, part-time, or less skilled work in another occupation. Group III persons represented $70-80$ percent of all persons with a disability.

${ }^{22}$ On changes in the mechanism for calculating pensions, see The Current Digest of the Soviet Press, 41 (45): 16-17.

${ }^{23}$ lbid.

${ }^{24}$ Feshbach and Friendly Jr., Ecocide, 160.

${ }^{2 s}$ Ibid.

${ }^{26}$ Station Relay 4 (1-5) (September 1988-May 1989): 91. Also see Bill Keller, "Comrade Engver Goes to Moscow," The New York Times Magazine, 27 August 1989: 25-7, 56-7, 62, 65.

${ }^{27}$ For more on the society, see The Station Relay 4 (1-5) (September 1988-May 1989): 78-84.

${ }^{29}$ Zaslavsky and his wife were also guests of honour at the World Institute on Disability in Berkeley, California in September 1989. 29Ibid.

${ }^{30}$ Izvestiya, 24 August 1989, 2; cited in The Station Relay 4 (1-5) (September 1988-May 1989): 94.

${ }^{31}$ Ibid.

32Ibid.

Mlbid.

MIbid.

"Izvestiya, 5 June 1989. 1; cited in Feshbach and Friendly Jr., Ecocide, 234-35.

${ }^{36}$ Despouy, Human Rights and Disabled Persons, 30, paragraph 212. "Ibid., 35, paragraph 242.

3see Stephen P. Dunn and Ethel Dunn, "Everyday Life of the Disabled," in William O. McCagg and Lewis Siegelbaum, eds., The Disabled in the Soviet Union, 222.

${ }^{39}$ For more on the V.I. Lenin Soviet Children's Fund, see Landon Pearson, "The V.I. Lenin Soviet Children's Fund: Community Support for the Special Child in the Soviet Union?," in John Dunstan, ed., Soviet Education Under Perestroika (London: Routledge Press, 1992): 118-27. Also see Uchitel'skaia gazeta [Teachers' Newspaper] 17 
(October), 2; Supplement to Moscow News 34 (1987): 6; Moscow News 47 (1987), 9; and The Station Relay 3 (3), January 1988: 28-9.

${ }^{40}$ For more on state response to the rapid growth of social groups during perestroika, see Jim Butterfield and Marcia Weigle, "Unofficial Social Groups and Regime Response in the Soviet Union," in Sedaitis and Butterfield, eds., Perestroika From Below, (Boulder, Colorado: Westview Press, 1991), 175-95.

"1zvestiya, 28 December 1988, 1; cited in The Current Digest of the Soviet Press 40 (52): 28.

"2Pearson, "The V.I. Lenin Soviet Children's Fund," 121-2.

4'/zvestiga, 17 September 1988, 2; cited in The Current Digest of the Soviet Press 40 (37): 19.

${ }^{4}$ At this time the increasing presence of Afghan war veterans in the media illustrated the inefficiencies of the Soviet prosthetics industry. Bureaucratization, lack of parts, shoddy production, cost inefficiency. and ineffective physician training, among others, had brought to light a need for a complete overhaul of the Soviet prosthetics industry. For more see The Station Relay 4 (1-5) (September 1988-May 1989): 93; Ogonek (21): 22-4; and Drew Hittenberger, "Sovict Prosthetics Workshop," Almanac (December 1989): 22-30.

"Matthews, "Perestroika and the Rebirth of Charity," 161.

${ }^{46}$ Pravda, 14 October 1988, 5; cited in The Current Digest of the Soviet Press 40 (41): 13. A 24-hour television fund raiser--the first of its kind-raised 61 million rubles in January 1990. See Pravda, 9 January 1990. ${ }^{47}$ Feshbach and Friendly Jr., Ecocide, 82

48Ibid., 84-6.

"Pearson, "The V.l. Lenin Soviet Children's Fund," 124.

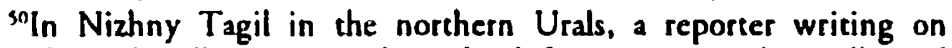
industrial pollution visited a school for persons with intellectual disabilities. Across the street and around the corner a metallurgical complex and a cement factory spewed pollutants into the air. "You go to school sometimes in a thick haze of smoke with your teeth gritting from the cement dust," a teacher remarked. "And you must never open the classroom windows. The sills turn gray in an instant." $\mathrm{L}$. Yermakova, "V ognyonnom ozherelye," Semya 22 (1990); cited in Feshbach and Friendly, Jr., Ecocide, 103.

"Some Western researchers believed the fund was biased in favour of the integration of children with a disability into the regular school system. This was not the position of the Soviet medical establishment. See Pearson, "The V.1. Lenin Soviet Children's Fund," 124-27; V. Lubovskii, "Some Urgent Problems of Soviet Work with Handicapped Children," Soviet Education 31 (5) (May 1989): 50-67; Andrew Sutton, "Special Education for Handicapped Pupils," in Riordan, "Playing to New Rules," 70-93. Also see Barbara A. Anderson, Brian D. Silver and Victoria A. Velkoff. "Education of the Handicapped in the USSR: Exploration of the Statistical Picture," Soviet Studies 39 (3) (July 1987): 468-88. 
32Ibid.

53 Pravda, 14 October 1988, 5; cited in The Current Digest of the Soviet Press 40 (41): 11-13.

${ }^{54}$ The Initiative Group to Defend the Rights of the Disabled in the USSR was formed in October 1978 at a press conference of the Moscow Helsinki Watch Group. Over the next four years, the Group was heavily involved in disability issues in particular and human rights in general. The Group also periodically published an information bulletin, detailing the cases of repression against persons with a disability. Members of the Group were also prosecuted and in some instances exiled. For more on the Group, see Ludmilla Alexeyeva, Soviet Dissent, Dunn and Dunn, "Everyday Life of the Disabled in the USSR"; Paul Raymond, "Disability as Dissidence: The Action Group to Defend the Rights of the Disabled in the USSR," in McCagg and Sicgelbaum, The Disabled in the USSR; Steven Marc Glick, "Disability in the USSR-A Dissident View: A Case Study of the Action Group to Defend the Rights of the Disabled in the USSR" (MA Thesis, London School of Economics, 1980); and Atkins, "Whither the 'New Soviet Man'?," 30-64.

"Isvestiya, 14 February 1988 18; cited in The Current Digest of the Soviet Press 40 (7): 24.

s6Ibid.

"7For an overview of the conference, see Izvestiya, 19 August 1988, 2. For more on occupational rehabilitation, see Izvestiya, 9 January 1990, 32.

s8" Oni' i 'my" [We and They], Ogonek, 42 (1988): 14-16; cited in The Station Relay 4 (1-5) (September 1988-May 1989): 85-6, 88.

${ }^{59}$ Sotsial'noe obespechenie [Social Security] (1) (1989): 39-40; cited in The Station Relay, 4 (1-5) (September 1988-May 1989): 85-90.

"Tlbid., 88.

${ }^{61}$ Sotsial'noe obespechenie [Social Security] 11 (1988).

${ }^{62}$ The Station Relay, 4 (1-5) (September 1988-May 1989): 88.

${ }^{63} \mathrm{~A}$ raion is comparable to a rural county or an urban ward.

${ }^{G} E$. Potapova, "Kogda est'opora"[When Support is Wearing Away], Sotsial'noe obespechenie [Social Security] 12 (1988): 40-2.

"Marilyn Golden, "Mission: Moscow," Challenge (January-February, 1989): 18-25. Also, Moscow News, 41 (1988), 4.

${ }^{6} \mathrm{~F}$ or a general analysis, see The Station Relay 4 (1-5) (September 1988-May 1989): 78-81; and Matthews, "Perestroika and the Rebirth of Charity." 163-5. Matthews remarks that in publicizing the concerns of local support groups and promoting appropriate response to it, "it is possible to perceive, in this respect, a distinct change of editorial policy in a number of leading newspapers"(163).

${ }^{67}$ For example, in a Moscow News, 8 (1989) survey, 72 percent of 800 people surveyed believed pensioners-especially those living alone, and peasants-were the least provided for and most needed the state's 
support. Thirty percent believed persons with a disability were the least provided for. Also see Moscow News. 32 (1988), 16; Moscow News, 10 (1990), 7; and Moscow News, 30 (1991), 9.

${ }^{68}$ Dunn and Dunn, "Everyday Life of the Disabled in the USSR," 228. ${ }^{69}$ Moscow News, 17 (1990), 15; 18 (1990), 2 and 11 (1991), 2; 37 (1988). Also sec Moscow News Supplement, 3 (1988), 5.

${ }^{70}$ Moscow News, 2 (1989), 2; 10 (1991), 14; no. 41 (1988), 4; and 31 (1989), 2.

"Ibid., 4 (1990), 2.

ribid., 41 (1989), 14.

${ }^{73}$ Ibid., 6 (1990), 2.

${ }^{74}$ Ogonek, 9 (February, 1988): 12-15.

"Moscow News, 38 (1990), 7.

${ }^{76}$ For more on the Salvation Army in Russia see Ibid., 4 (1992), 6.

nFeshbach and Friendly Jr., Ecocide. 230. 